\title{
Breakdown of gastric mucus in presence of Helicobacter pylori
}

\author{
R L Sidebotham, J J Batten, Q N Karim, J Spencer, J H Baron
}

\begin{abstract}
The potential of Helicobacter pylori to degrade gastric mucus was examined. Colonies of $\boldsymbol{H}$ pylori cultured from antral mucosal biopsy specimens of patients with non-autoimmune gastritis were washed with sterile saline, passed through a sterilisation filter, and the filtrate examined for urease, protease, and mucolytic activity. The filtrate failed to hydrolyse bovine serum albumin, or to degrade stable mucus glycoprotein structures of high particle weight that had been separated from human gastric mucus on Sepharose 2B. The high particle weight mucus glycoprotein was, however, extensively degraded when incubated with $H$ pylori filtrate (which possessed urease activity) in the presence of $2 \mathrm{M}$ urea, to release fragments of $M r \sim 2 \times 10^{6}$. The high particle weight mucus glycoprotein was also broken down to a comparable extent when incubated with Jack bean urease in the presence of $2 \mathrm{M}$ urea, or $1 \mathrm{M}$ ammonium carbonate, or $40 \mathrm{mM}$ carbonate-bicarbonate buffer (pH 8.7), but not when treated with $4 \mathrm{M}$ urea alone, or Jack bean urease alone. These results indicate that the loss of high particle weight mucus glycoprotein in gastric mucus from patients with gastritis and gastric ulcers is unlikely to be due to the mucolytic action of an extra-cellular protease produced by $H$ pylori, but it may result from the destabilising effects of a carbonate-bicarbonate buffer, generated at the mucosal surface when $H$ pylori urease hydrolyses transuded plasma urea.
\end{abstract}

Department of Surgery, Royal Postgraduate Medical School, Hammersmith Hospital, Du Cane Road, London W12 0NN

R L Sidebotham

J J Batten

J Spencer

J H Baron

Department of

Bacteriology,

St Mary's Hospital

Medical School,

London

Q N Karim

Correspondence to:

Dr J H Baron

Accepted for publication

16 August 1990 report ${ }^{45}$ specifically implicat A ra-cellular protease produced by $H$ pylori, a Gram negative bacterium that infects the gastric mucosa in most patients with gastric ulcer. ${ }^{67}$ We examined this claim and tested the hypothesis that decreased high particle weight mucus glycoprotein in mucus from patients with gastric ulcer is a consequence of the urease activity of $H$ pylori.

\section{Methods}

Gastric juice was aspirated continuously from healthy volunteers and collected on ice in 10 minute fractions for 90 minutes during intravenous infusion of pentagastrin $(6 \mu \mathrm{g} \mathrm{kg})$ hour). ${ }^{8}$ The nine 10 minute fractions of stimulated juice were adjusted to $\mathrm{pH} 8$ within five minutes of the end of the collection period, pooled, homogenised to disperse insoluble mucus, and clarified by centrifugation at 2000 $\times g$ for 10 minutes. The juice was concentrated (when necessary) to about $200-300 \mathrm{ml}$ by evaporation in a vacuum at $40^{\circ} \mathrm{C}$ and dialysed for 72 hours against three lots of 5 litres of deionised water at $4^{\circ} \mathrm{C}$ to remove salts, peptides, amino acids and phenol red marker dye. ${ }^{8}$ The non-dialysable material, consisting of mucus, pepsin, and plasma macromolecules, was then lyophilised. Non-dialysable material $(400 \mathrm{mg})$ was dispersed in $0.01 \mathrm{M} \mathrm{NaCl}(40 \mathrm{ml})$ and the high particle weight mucus glycoprotein separated from lower molecular weight mucus glycoprotein structures of smaller size, pepsin, and plasma macromolecules by chromatography on a column $(100 \times 5 \mathrm{~cm})$ of Sepharose 2B eluted with $0.01 \mathrm{M} \mathrm{NaCl}$ plus $0.02 \%$ sodium azide. The separation was monitored by quantitative reaction of fractions (each $10 \mathrm{ml}$ ) with phenol-sulphuric acid reagent. ${ }^{9}$ Fractions containing the high particle weight mucus glycoprotein, which eluted in the void volume (Vo) of the column, were combined, concentrated (as described) until the neutral hexose content was $2 \mathrm{mg} / \mathrm{ml}$ (measured with phenol-sulphuric acid), and stored at $4^{\circ} \mathrm{C}$. Yields were equivalent to $50 \mathrm{mg}$ mucus glycoprotein. The high particle weight mucus glycoprotein was not purified further, to avoid the possibility of structural breakdown.

$H$ pylori cultured from antral mucosal biopsy specimens obtained from patients with type B (non-autoimmune) gastritis, were initially cultured on $7 \%$ blood agar, made selective by the incorporation of IsoVitalex ( $1 \%)$, vancomycin (6 mg/l), nalidixic acid $(20 \mathrm{mg} / \mathrm{l})$ and amphotericin $(2 \mathrm{mg} / \mathrm{l})$. The bacteria were incubated in a microaerophilic atmosphere, established with the use of an Oxoid gas generating kit (No BR 60 ), at $37^{\circ} \mathrm{C}$ for three days.

Isolates were subcultured on $7 \%$ non-selective blood agar under identical conditions 
before the plates were gently washed with sterile saline ( $5 \mathrm{ml} \mathrm{a}$ plate) and the wash solution centrifuged $(2000 \times g / 10$ minutes $)$ and passed successively through Millipore sterilisation filters $(0.45$ and $0.2 \mu \mathrm{m})$ to retain the bacteria. The filtrate was stored at $4^{\circ} \mathrm{C}$ with sterility confirmed by culture. The protein content of the $H$ pylori filtrate was determined by the Lowry method, as modified ${ }^{10}$ with bovine serum albumin as standard.

$\mathrm{N}, \mathrm{N}$ dimethylated ${ }^{11}$ bovine serum albumin ( $5 \mathrm{mg}$ ) was incubated for 20 hours at $37^{\circ} \mathrm{C}$ in $0 \cdot 1$ $\mathrm{M}$ TRIS- $\mathrm{HCl}$ buffer containing $5 \mathrm{mM}$ calcium chloride, $\mathrm{pH} 7.8(10 \mathrm{ml})$, with (i) $H$ pylori filtrate $(1 \mathrm{ml})$, (ii) pronase (BDH 70000$)$ proteinase activity unit of kakem (units/g; 125 $\mu \mathrm{g}$ ) as a control, and (iii) boiled filtrate or boiled pronase, serving as reagent blanks. Aliquots $(500 \mu \mathrm{l})$ were removed from these mixtures at suitable intervals, and proteolytic breakdown monitored by measuring (a) released $\alpha$ amino residues with ninhydrin, ${ }^{12}$ and (b) low molecular weight peptides as described, ${ }^{10}$ after removal of undigested protein from the aliquot by precipitation with trichloroacetic acid $(2 \% \mathrm{w} / \mathrm{v})$

Gel electrophoresis of (i) $H$ pylori filtrate, (ii) bovine serum albumin (BSA), and (iii) BSA after incubation with $H$ pylori filtrate for 20 hours at $37^{\circ} \mathrm{C}$ (as described) was performed according to the method of Laemmli. ${ }^{13}$ Samples (10-200 $\mu \mathrm{g}$ protein per lane) were preincubated in $1 \%$ sodium dodecyl sulphate and $M$ mercaptoethanol, and separated at a constant current $(80 \mathrm{~mA})$ for 12 hours. Gels were stained for protein with polyacrylamide gel electrophoresis Blue G-90 $(0.04 \% \mathrm{w} / \mathrm{v})$ in perchloric acid $(3.5 \% \mathrm{w} / \mathrm{v})$, and diffusion destained in $2.5 \%$ aqueous methanol containing $7.5 \%$ acetic acid.

The urease activity of the $H$ pylori filtrate was determined by measuring the release of ammonia ${ }^{14}$ from urea substrate at $37^{\circ} \mathrm{C}$ in the presence of $0.085 \mathrm{M}$ phosphate buffer, $\mathrm{pH} 8$. Mean urease activity was $2 \mu \mathrm{M}$ units $/ \mathrm{ml}$ of filtrate (when $1 \mu \mathrm{M}$ unit catalyses the hydrolysis of $0.5 \mu \mathrm{M}$ urea/minute at $37^{\circ} \mathrm{C}, \mathrm{pH}$ 8 ), and was not greatly affected by storage at $4^{\circ} \mathrm{C}$ for two weeks.

Gastric mucosal pH $(\leqslant 7 \cdot 4)$ should rise in $H$ pylori infection as transuded plasma urea (between $5-10 \mathrm{mM}$ ) is hydrolysed by the bacterial urease in presence of mucosal/transuded bicarbonate (between 20-30 mM). The following experiment was designed to assess how hydrolysis of urea might affect mucosal $\mathrm{pH}$ in the vicinity of the bacterium.

Changes in $\mathrm{pH}$ when urea-bicarbonate solutions are incubated with $H$ pylori filtrate

\begin{tabular}{lllc}
\hline & $p H$ & \multicolumn{3}{l}{$\begin{array}{l}\text { Incubation } \\
\text { time (hours) }\end{array}$} & $\begin{array}{l}5 \mathrm{mM} \text { urea-30 } \mathrm{mM} \\
\text { bicarbonate solution }\end{array}$ & $\begin{array}{l}10 \mathrm{mM} \text { urea-30 } \mathrm{mM} \\
\text { bicarbonate solution }\end{array}$ \\
\hline 0 & $7 \cdot 4$ & $7 \cdot 4$ & $7 \cdot 4^{\star}$ \\
$1 \cdot 5$ & $8 \cdot 3$ & $8 \cdot 5$ & $7 \cdot 8$ \\
3 & $8 \cdot 7$ & $8 \cdot 8$ & $7 \cdot 9$ \\
5 & $8 \cdot 8$ & $9 \cdot 1$ & $8 \cdot 1$ \\
24 & $8 \cdot 7$ & $9 \cdot 0$ & $8 \cdot 1$ \\
\hline${ }^{\star} H$ pylori filtrate omitted in control. & \multicolumn{3}{l}{} \\
\hline
\end{tabular}

Sodium bicarbonate solution ( $30 \mathrm{mM} ; 10 \mathrm{ml})$ was gassed to $\mathrm{pH} 7 \cdot 4$ with carbon dioxide, and sufficient urea was added to make the solution either $5 \mathrm{mM}$ or $10 \mathrm{mM}$ with respect to the urea. The urea-bicarbonate solution was then incubated with $H$ pylori filtrate $(250 \mu \mathrm{l} ; 7 \mu \mathrm{M}$ urease units/ml: sufficient enzyme to hydrolyse all the urea in the $10 \mathrm{mM}$ solution in two hours at the optimal reaction rate) in a sealed drum phial at $37^{\circ} \mathrm{C}$, and the $\mathrm{pH}$ recorded after one and a half, three, five and 24 hours. The results are summarised in the table.

High particle weight mucus glycoprotein (Vo concentrate from the Sepharose 2B column; $1 \mathrm{ml}$ ) was incubated for 20 hours at $37^{\circ} \mathrm{C}$ (i) alone, and (ii) in the presence of the following: (a) $H$ pylori filtrate $(200 \mu \mathrm{l})$; (b) $H$ pylori filtrate plus $2 \mathrm{M}$ urea; (c) Jack bean urease (BDH $95000 \mu \mathrm{M}$ units/g; $100 \mu \mathrm{g}$ ); (d) Jack bean urease plus $2 \mathrm{M}$ urea; (e) $4 \mathrm{M}$ urea; (f) $1 \mathrm{M}$ ammonium carbonate; (g) a buffer ( $\mathrm{pH}$ $8 \cdot 7$ ), consisting of $10 \mathrm{mM}$ ammonium carbonate plus $30 \mathrm{mM} \mathrm{NaHCO}$; and (h) Sigma porcine pepsin $(2 \% \mathrm{w} / \mathrm{w})$. The volume of each solution was adjusted to $2.5 \mathrm{ml}$ before incubation, by addition of an appropriate volume of buffer or deionised water. This reduced the concentration of $\mathrm{NaCl}$ (from the Sepharose 2B column eluant) to about $20 \mathrm{mM}$. Breakdown of the high particle weight mucus glycoprotein was assessed by quantitative reaction with phenol-sulphuric acid ${ }^{9}$ after separation of high particle weight mucus glycoprotein (Vo) low molecular weight structures of smaller size on a column $(1 \times 70 \mathrm{~cm})$ of Sepharose $2 \mathrm{~B}$ eluted with $0.05 \mathrm{M} \mathrm{NaCl}$. The column was calibrated with "highly polymerised" calf thymus DNA

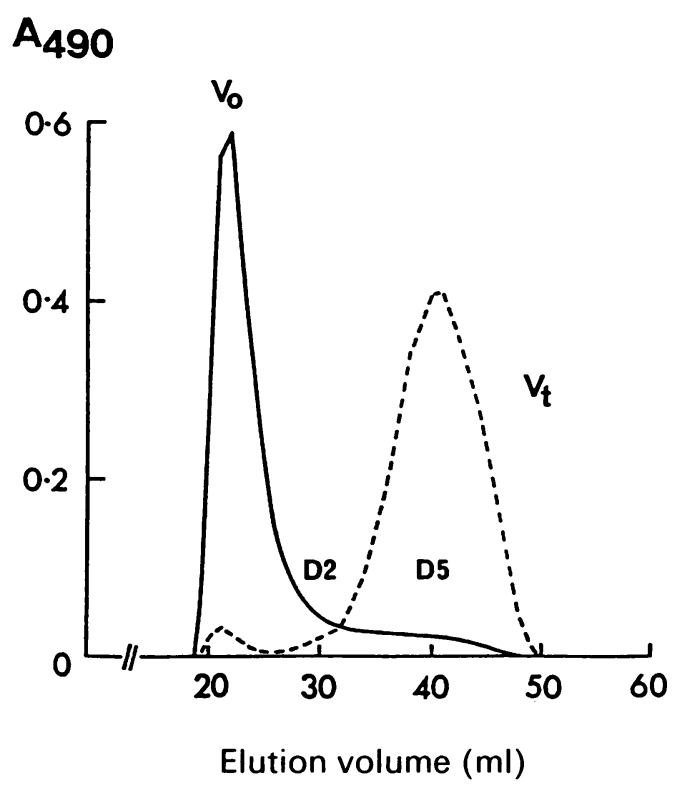

Figure 1 Chromatography on Sepharose $2 B(1 \times 70 \mathrm{~cm}$ column eluted with $0.05 \mathrm{M} \mathrm{NaCl}$, of porcine gastric mucus before (-) and after (-.-) proteolysis ( Sigma pronase $2 \%$ w/w in $0.1 \mathrm{M}$ TRIS-HCl buffer; $\mathrm{pH} 7.8$ at $37^{\circ} \mathrm{C}$ for 24 hours) with reduction (dithiothreitol $2 \%$ w/w for four hours). Void volume (Vo), total volume (Vt), dextran 2000 (D2), dextran T500 (D5).

Separations were monitored with phenol-sulphuric acid. 
Figure 2 SDS-PAGE of bovine serum albumin ( $B S A$ ), $H$ pylori filtrate, and $B S A$ after incubation with $H$ pylori filtrate. After electrophoresis the gel was stained for protein Lane $1 B S A$, lane $2 B S A$ after incubation with $H$ pylori filtrate for 20 hours at $37^{\circ} \mathrm{C}$, and lane $3 \mathrm{H}$ pylori filtrate $(200 \mu \mathrm{g}$ protein; about 10 times the amount of filtrate-protein applied to lane 2).

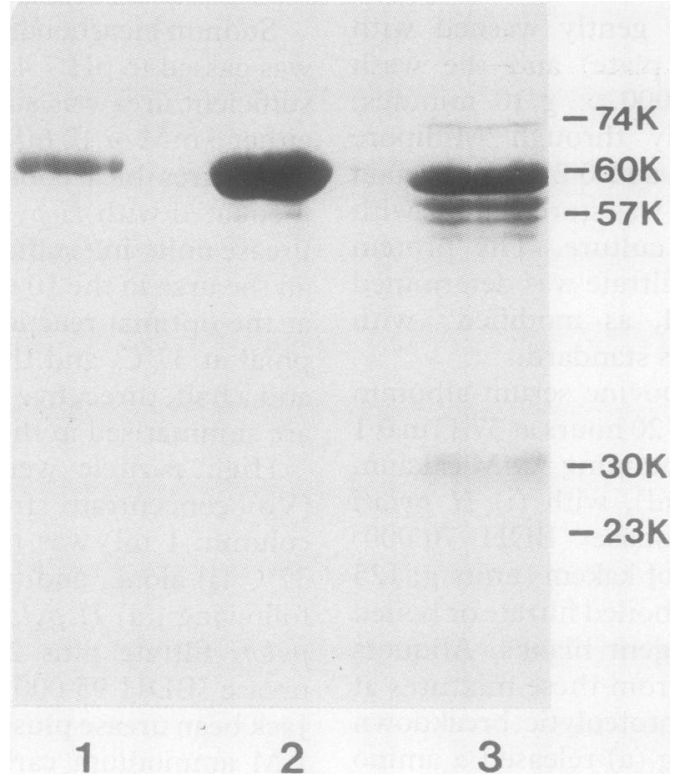

(Vo marker), glucose (Vt marker), dextran 2000 $\left(\mathrm{Mr} \sim 2 \times 10^{6}\right)$, dextran T500 $\left(\mathrm{Mr} \sim 5 \times 10^{5}\right)$, and with porcine gastric mucus (fig 1). Mean distribution coefficients (Kav) of components on Sepharose 2B were calculated as described. ${ }^{15}$

\section{Results}

A sterile filtrate of $H$ pylori was found to contain seven protein bands when examined by SDS-polyacrylamide electrophoresis (fig 2). The major band corresponded to a molecular weight of 60 kilodaltons, with less prominent

Figure 3 The release of ( $A$ ) x-amino residues (A570 after reaction with ninhydrin) and (B) low molecular weight peptides ( A650 after reaction with Folin-Ciocalteau reagent) from bovine serum albumin on incubation with pronase (1), and $H$ pylori filtrate - in 0.1MTRIS$\mathrm{HCl} ; \mathrm{pH} 7 \cdot 8$, at $37^{\circ} \mathrm{C}$.

\section{$A_{570}$}

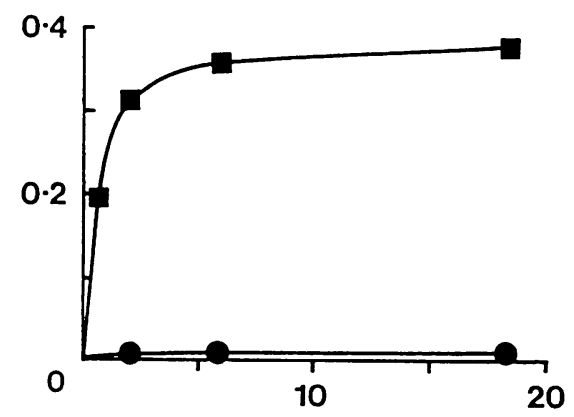

$A_{650}$

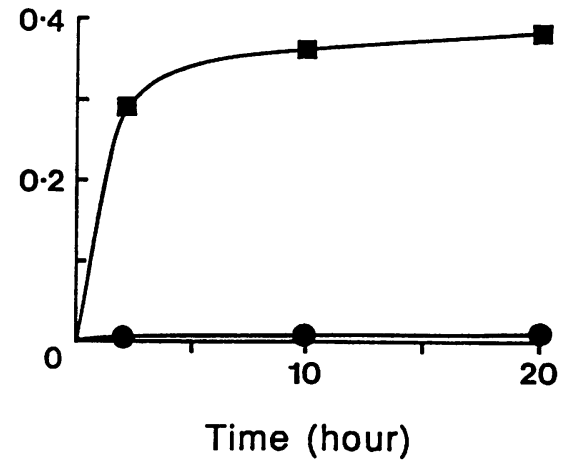

bands at 74, 58, 57, 54, 30 and 23 kilodaltons. At least three of these proteins seem to be associated with urease activity in the filtrate. ${ }^{16}$ When incubated with 5 or $10 \mathrm{mM}$ urea-bicarbonate solution $H$ pylori filtrate raised the $\mathrm{pH}$ from 7.4 to (at least) 8.8 in five hours (table).

No hydrolysis of bovine serum albumin could be discerned after incubation with $H$ pylori filtrate (even when freshly prepared) for 20 hours at $37^{\circ} \mathrm{C}$, when breakdown was monitored by SDS-polyacrylamide electrophoresis (fig 2), or spectrophotometric methods (fig 3).

Breakdown of high particle weight mucus glycoprotein was negligible (when compared with that achieved with pepsin) after incubation with $H$ pylori filtrate for 20 hours at $37^{\circ} \mathrm{C}$ (fig 4B). In contrast, extensive breakdown of high particle weight mucus glycoprotein was observed on incubation with $\mathrm{H}$ pylori filtrate to which had been added $2 \mathrm{M}$ urea (fig $4 \mathrm{C}$ ). A comparable breakdown of high particle weight mucus glycoprotein occurred after incubation with Jack bean urease in the presence of $2 \mathrm{M}$ urea, $1 \mathrm{M}$ ammonium carbonate (fig $4 \mathrm{C}$ ), and a buffer ( $\mathrm{pH} \mathrm{8.7)} \mathrm{containing} 10 \mathrm{mM}$ ammonium carbonate and $30 \mathrm{mM} \mathrm{NaHCO}$ (fig 4D), but was negligible when high particle weight mucus glycoprotein was treated for the same period of time with $4 \mathrm{M}$ urea, or Jack bean urease alone (fig 4B). The major fragment arising from breakdown of high particle weight mucus glycoprotein had a mean distribution coefficient (Kav) of $\mathbf{0} \cdot 26$. This was considerably less than that of dextran T500 (Kav 0.69), or of the product of limit proteolysis/reduction of gastric mucus (fig 1), but equivalent to that of dextran 2000, and of a mucus glycoprotein structure isolated from porcine gastric mucus with $\mathrm{Mr} \sim 2 \times 10^{6} .{ }^{17} 18$

We noted that the elution profile shown in fig $4 \mathrm{D}$ was exactly reproduced when the gelexcluded (Vo) and gel-included mucus glycoprotein structures depicted in fig $4 \mathrm{D}$ were separately chromatographed again on Sepharose $2 \mathrm{~B}$. This indicated that the gel-excluded mucus glycoprotein structure in fig 4D was not identical with the original high particle weight mucus glycoprotein shown in fig $4 \mathrm{~A}$, but a less stable aggregate formed by association of mucus glycoprotein structures of $\mathrm{Mr} \sim 2 \times$ $10^{6}$. Allen et al have also reported in vitro aggregation of mucus glycoprotein structures of $\mathrm{Mr} \sim 2 \times 10^{6} .{ }^{19}$ Comparison of fig $4 \mathrm{C}$ and fig $4 \mathrm{D}$ further suggested that the potential for aggregation of mucus glycoprotein structures of $\mathrm{Mr} \sim 2 \times 10^{6}$ is determined by conditions under which the high particle weight mucus glycoprotein was initially fragmented. It is noteworthy that the ratio of the Sepharose 2B gel-excluded and gel-included mucus glycoprotein structures, after incubation of high particle weight mucus glycoprotein in carbonate-bicarbonate buffer (fig 4D), is similar to that seen in the elution profile on Sepharose $2 B$ of mucus aspirated from patients with gastric ulcer or gastritis (fig 5 ), and mucus removed from the gastric mucosal surface of rats with increased susceptibility to ulceration induced by aspirin. ${ }^{20}$ 
Figure 4

Chromatography on

Sepharose $2 B(1 \times 70 \mathrm{~cm}$

column eluted with $0.05 \mathrm{M}$

$\mathrm{NaCl}$ ) of high particle

weight mucus glycoprotein

(A) before and after

incubation alone (-),

and after (----)

proteolysis with Sigma

porcine pepsin $12 \%$ w/w in

$0 \cdot 1 \mathrm{M} \mathrm{KCl}-\mathrm{HCl}$ buffer;

pH 2); (B) after

incubation with $H$ pylori

filtrate, or Jack bean

urease or $4 M$ urea,

(C) after incubation with

$H$ pylori filtrate $+2 M$

urea, or Jack bean urease

$+2 M$ urea, or $1 M$

ammonium carbonate,

(D) after incubation with

ammonium carbonate-

$\mathrm{NaHCO}_{3}$ buffer; pH 8.7.

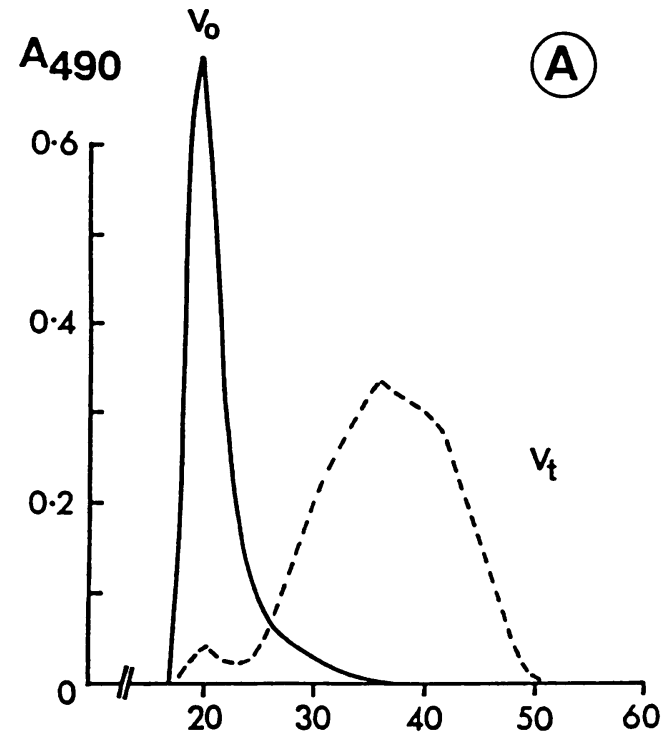

$A_{490}$

(B)
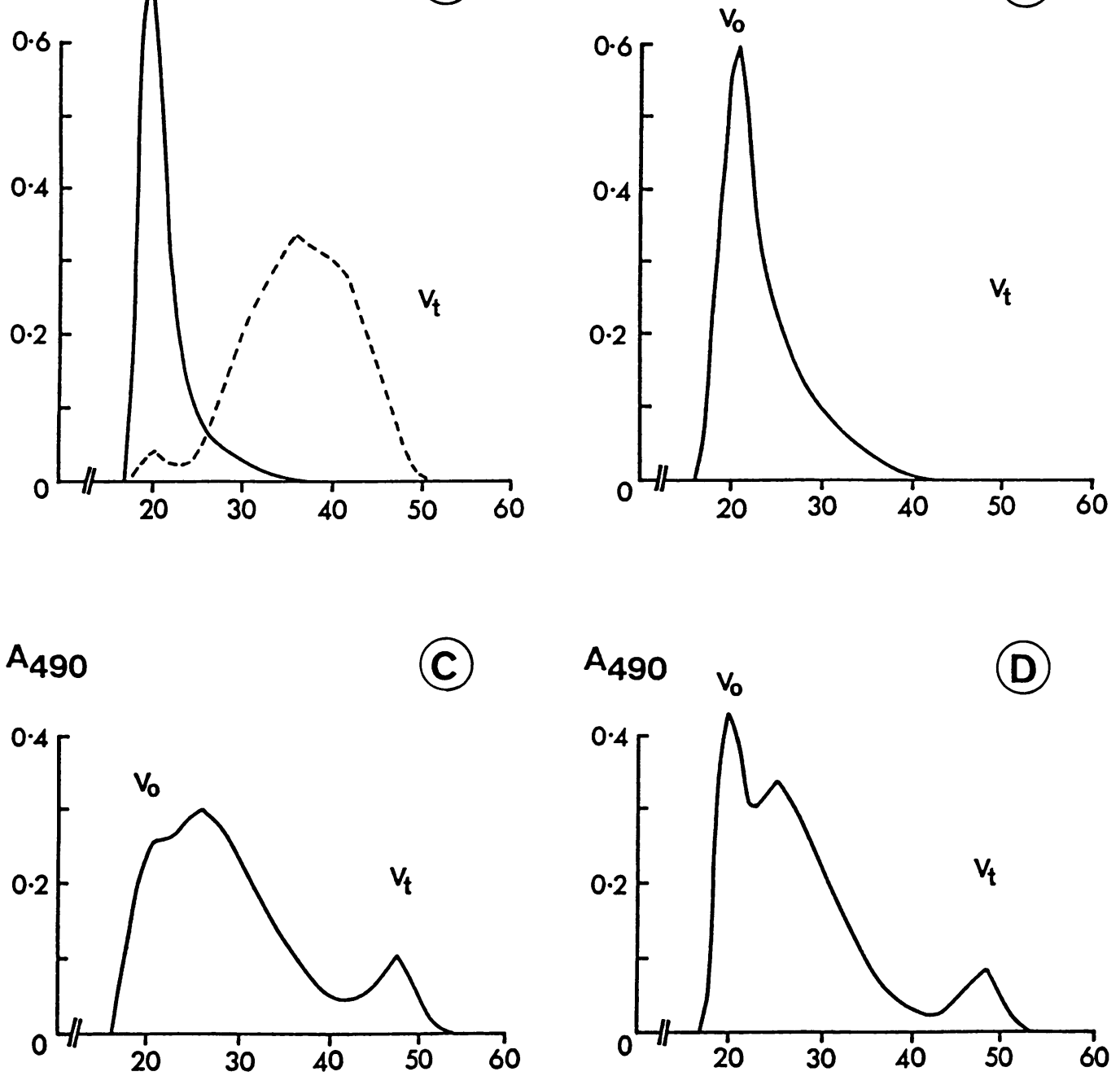

Elution volume $(\mathrm{ml})$

Figure 5

Chromatography on

Sepharose $2 B 11 \times 70 \mathrm{~cm}$

column eluted with $0.05 \mathrm{M}$

$\mathrm{NaCl}$ ) of mucus (non-

dialysable) aspirated from

( A) volunteers and ( $B$ )

patients with gastric ulcer

material and gastritis.

Fractions containing

plasma glycoprotein

denoted (圖) and mucus

glycoprotein (」). The

mucus glycoprotein was

delineated by reference to

the elution profile of

porcine gastric mucus ( fig

1 , , and was excluded from

Bio-Gel $A$ 0.5 $m$ after

digestion with Sigma

pronase, $2 \%$ w/w in $0 \cdot 1 \mathrm{M}$

TRIS-HCl buffer; $\mathrm{pH}$

$7 \cdot 8$, at $37^{\circ} \mathrm{C}$ for 24 hours.

Separations were

monitored with phenol-

sulphuric acid.

$A_{490}$

(A)

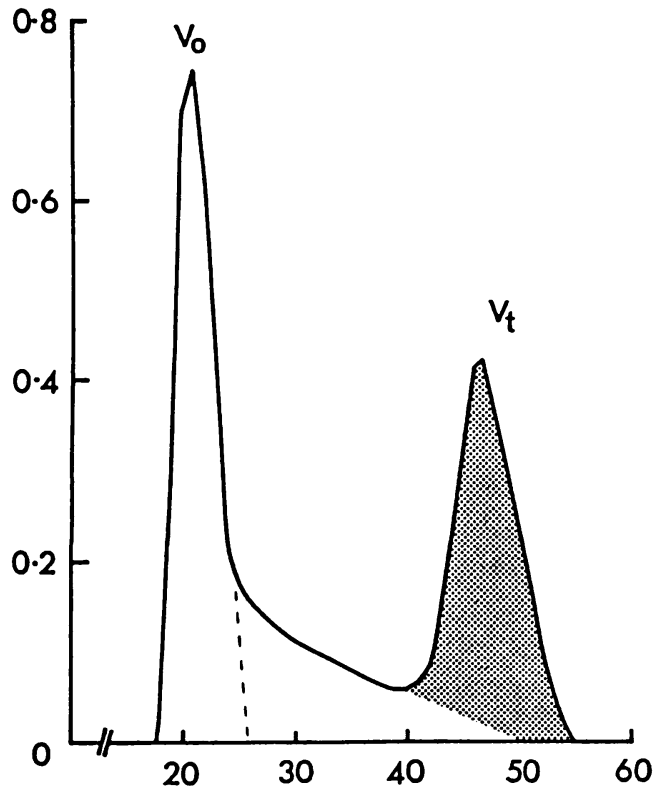

(B)

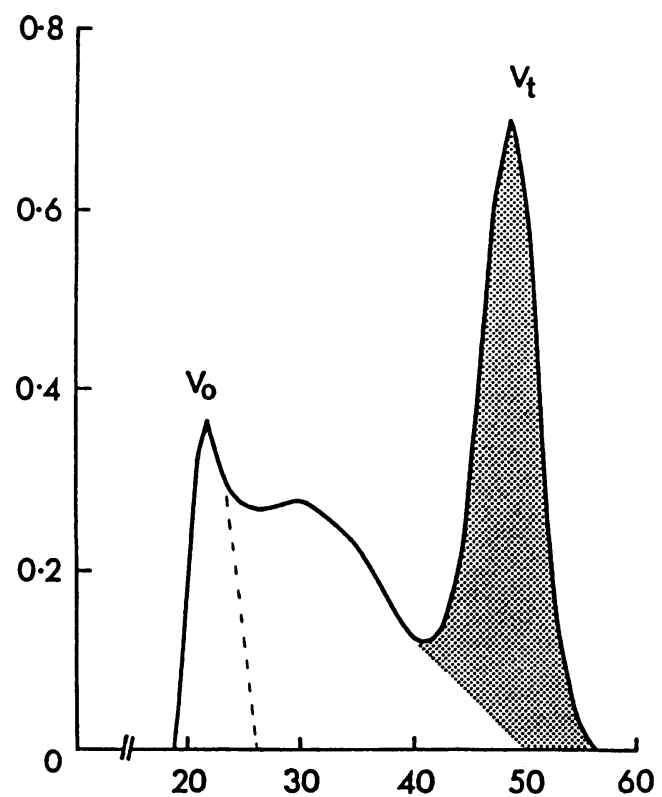

Elution volume $(\mathrm{ml})$ 


\section{Discussion}

A sterile filtrate of $H$ pylori, prepared in our laboratory in accordance with the procedure outlined by Slomiany et al, ${ }^{4}$ failed to hydrolyse bovine serum albumin, or to break down high particle weight mucus glycoprotein, as described. ${ }^{45}$ These findings cast further doubt ${ }^{21}$ on the authenticity of a recent report of an extra-cellular $H$ pylori protease with mucolytic activity, ${ }^{45}$ and prompted us to seek an alternative cause of the degradative effect of $H$ pylori filtrate on gastric mucus.

We noted that Fitzgerald and Murphy had administered $8 \mathrm{M}$ urea to patients with peptic ulcer anticipating that ammonium carbonate, released by the activity of urease in the gastric mucosa, would neutralise stomach acid..$^{22}$ The treatment was not well tolerated, and there was evidence of an irritant effect of the ammoniacal milieu on the gastric mucosa. Since then, the destructive effects of urea in the presence of urease $^{23}$ and of exogenous ${ }^{2324}$ and endogenous $^{25}{ }^{26}$ ammonia on the gastric mucosal barrier have been detailed by other authors. These observations suggested that the in vitro mucus breakdown reported by Slomiany $e t$ al might be attributable to a mucolytic action of ammonium carbonate, released by hydrolysis of $6 \mathrm{M}$ urea which had been incorporated into the column eluant when fractionating $H$ pylori filtrate-incubation mixtures. ${ }^{4}$ This hypothesis was tested by incubating high particle weight mucus glycoprotein with $H$ pylori filtrate in the presence of $2 \mathrm{M}$ urea. Under these conditions breakdown of high particle weight mucus glycoprotein was extensive, although fragments were larger $\left(\mathrm{Mr} \sim 2 \times 10^{6}\right)$ than are produced by pepsin proteolysis, and exhibited a limited potential for aggregation. Incubation of high molecular weight mucus glycoprotein with Jack bean urease in the presence and absence of $2 \mathrm{M}$ urea, $4 \mathrm{M}$ urea, and $1 \mathrm{M}$ ammonium carbonate confirmed that the breakdown was mediated through urease activity in the $H$ pylori filtrate.

The extent to which $H$ pylori urease was able to degrade mucus in our in vitro experiments was of particular interest, as a potential cause of decreased high particle weight mucus glycoprotein in mucus aspirated from patients with gastric ulcer or gastritis. ${ }^{2}$ Human plasma nor-
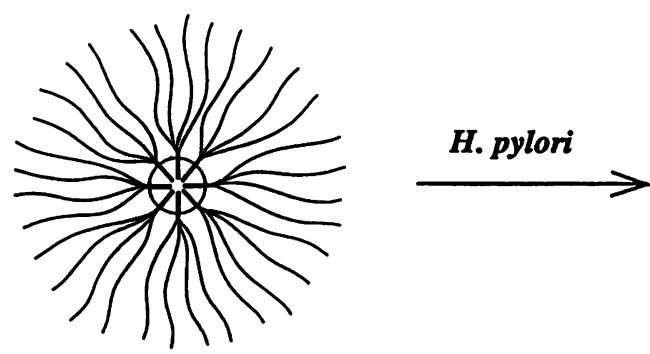

STRUCTURE I mally contains $5-10 \mathrm{mM}$ urea ${ }^{27}{ }^{28}$ Marshall has indicated that a mean of $85 \%$ of transuded plasma urea is hydrolysed (to ammonium carbonate) by urease in patients with $H$ pylori infection, ${ }^{29}$ and indeed the concentration of ammonia is reported to reach $25 \mathrm{mM}$ (equivalent to $12.5 \mathrm{mM}$ ammonium carbonate) in mucus from such patients. ${ }^{30}$ In solution ammonium carbonate partially decomposes to form a carbonate-bicarbonate buffer system. When the contribution of plasma/mucosal bicarbonate ${ }^{27}$ is taken into consideration, the hydrolysis of transuded plasma urea could, in theory, generate a $25-50 \mathrm{mM}$ carbonate-bicarbonate buffer ( $\mathrm{pH} 9)$ at the gastric mucosal surface. We therefore examined the in vitro effects of such a buffer $(10 \mathrm{mM}$ ammonium carbonate plus $30 \mathrm{mM} \mathrm{NaHCO}$; $\mathrm{pH} 8 \cdot 7$ ) on high particle weight mucus glycoprotein. Breakdown of high particle weight mucus glycoprotein was extensive, causing fragments of $\mathrm{Mr} \sim 2 \times 10^{6}$ (with a noticeable potential for aggregation) to be released.

These data support a role for $H$ pylori urease in the in vivo breakdown of human gastric mucus. This may be brought about by the mechanism summarised in fig 6 . Gastric mucus is a gel formed from mucus glycoproteins. These macromolecules are bound into complex structures: mucus glycoprotein of $\mathrm{Mr} \sim 5 \times$ $10^{5}$ are cross-linked through proteins to form mucus glycoprotein complexes (structure II) of $\mathrm{Mr} \sim 2 \times 10^{6},{ }^{31}$ which are incorporated with lipids ${ }^{532}$ into very large spherical or ellipsoidal micelles. ${ }^{33-34}$ The micelles then interact to form the mucus layer and endow it with the properties of elasticity, hydrophobicity, and resistance to proteolysis. In $H$ pylori infection we envisage that (i) $\mathrm{pH}$ is increased to about 9 in the vicinity of the bacterium, by the action of urease on transuded plasma urea, (ii) $\mathrm{pH}$ sensitive protein-lipid interactions, ${ }^{35}$ that normally stabilise structure I are broken, and (iii) the now destabilised structure I is disassembled, perhaps by the "corkscrewing" motility of $H$ pylori $^{36}$ to release structure II. This mechanism may be of pathological importance in facilitating $H$ pylori colonisation of gastric mucosa (which seems to be urease dependen $t^{37}$ ) and promoting peptic ulceration. ${ }^{3}$

We are grateful to the Smith Kline (1982) Foundation, the Peel Medical Research Trust, and the Mason Medical Research Foundation for their gifts of equipment used in this work. We thank Mr John Fleming for constructive discussions.

1 Younan F, Pearson JP, Allen A, Venables C. Changes in the structure of the mucous gel on the mucosal surface of the stomach in association with peptic ulcer disease. Gastrostomach in association with
enterology 1982;82:827-31.

2 Batten JJ, Sidebotham RL, Spencer J, Baron JH. Changes to mucus glycoprotein structures in patients with gastritis mucus glycoprotein structures in patients with gastritis 21): $1-8$.

3 Sidebotham RL, Baron JH. Hypothesis: Helicobacter pylori, urease, mucus and gastric ulcer. Lancet 1990; 335:193-5

4 Slomiany BL, Bilski J, Sarosiek J, et al. Campylobacter pyloridis degrades mucin and undermines gastric mucosal integrity. Biochem Biophys Res Commun 1987;144:307-14.

5 Sarosiek J, Slomiany A, Slomiany BL. Evidence for weakening of gastric mucus integrity by Campylobacter pylori. Scand J Gastroenterol 1988;23:585-90

6 O'Connor HJ, Dixon MF, Wyatt JI, Axon ATR. Campylobacter positive and Campylobacter negative gastric ulcers, have they a different aetiology? Gut 1986;27: A1282.

Figure 6 The in vivo breakdown of gastric mucus by $H$ pylori. It is envisaged that micellar structure I is destabilised and disaggregated when the mucosal $p H$ rises to 8.7 by the action of $H$ pylori urease on transuded plasma urea. Hydrophobic structure (lipids) $O$, mucus glycoprotein (MG), "link" protein dimers $(P)$. 
7 Coelho LGV, Das SS, Payne A, Karim QN, Baron HJ, Walker MM. Campylobacter pylori in oesophagus, antrum and duodenum. A histological and microbiological study. Dig Dis Sci 1989;34:445-8.

8 McCloy RF. In: Baron JH. Clinical tests of gastric secretionhistory, methodology and interpretation. London: Macmillan, 1978:212-17.

9 Dubois M, Gillies KA, Hamilton JK, Rebers PA, Smith F. Colorimetric method for determination of sugars and related substances. Anal Chem 1956;28:350-6.

10 Schacterle GR, Pollack RL. A simplified method for the quantitative assay of small amounts of protein in biological material. Anal Biochem 1973;51:654-5.

11 Lin Y, Means GE, Feeney RE. The action of proteolytic enzymes on N,N-dimethyl proteins. J Biol Chem 1969; 244:789-93.

12 Moore S, Stein WH. Photometric ninhydrin method for use in the chromatography of amino acids. J Biol Chem 1948;176:367-88.

13 Laemmli UK. Cleavage of structural proteins during the assembly of the head of bacteriophage T4. Nature 1970;277:680-5.

14 Varley H, Gowenlock AH, Bell M, eds. Practical Clinical Biochemistry. Vol 1. London: Heinemann, 1980:457-8.

15 Anon. Gel chromatography. Richmond, California: Bio-Rad Laboratories, 1975:15-18.

16 Newell DG, Stacey A. Antigens for the serodiagnosis of Campylobacter pylori infections. Gastroenterol Clin Biol 1989;13:37b-41b.

17 Carlstedt I, Sheehan JK. Macromolecular properties and polymeric structure of mucus glycoproteins. In: Mucus and Mucosa, CIBA Symposium 109. London: Pitman, 1984:157-72.

18 Allen A, Pearson JP, Hutton DA, Mall AH, Coan RM, Sellers LA. The dependence of size and functional properties of pig gastric mucus on the isolation method. Soc Exp Biol 1989;43:241-8.

19 Allen A, Hutton DA, Mantle D, Pain RH. Structure and gel formation in pig gastric mucus. Biochem Soc Trans 1984;12:612-15.

20 Bagshaw PF, Munster DJ, Wilson JG. Molecular weight of gastric mucus glycoprotein is a determinant of the degree of subsequent aspirin-induced chronic ulceration in the rat. Gut 1987;28:287-93.

21 Andersen LP, Holck S, Povlsen CO, Elsborg L, Justesen T. Campylobacter pyloridis in peptic ulcer disease. Scand $J$ Gastroenterol 1987;22:219-24.

22 Fitzgerald $O$, Murphy $P$. Studies on the physiological chemistry and clinical significance of urease and urea with special reference to the stomach. Irish J Med Sci 1950; 292:97-159.
23 Murakami M, Yoo JK, Inada M, Miyaki T. Effect of ammonia on the gastric mucosa in rats: pathophysiological importance of urease in gastric ulcer disease. Japan $J$ Pharmacol 1988;47:330-2

24 Tsujii M, Kawasano S, Sato N, Kamada T. Campylobacter pylori infection decreases the intracellular mucin of human gastric mucosa. Gastroenterology 1989;96:A517

25 Imoto I, Yoshida Y, Suzuki S. Campylobacter pylori infection and ammonia on the gastric mucosal damage. Gastroenterol Intern 1988;1(Suppl 1):A683.

26 Yoshida M, Imoto I, Shida Y, Suzuki S. The significance of Campylobacter pylori infection on the development of gastric mucosal injury-urease-protease theory. Gastroenterology 1989;96:A562.

27 Long C, ed. Biochemists handbook. London: E and FN Spon Ltd, 1961:850-51, 873.

28 Snook J. Urea/creatinine ratio and gastrointestinal haemorrhage. Lancet 1986;ii:400.

29 Marshall BJ, Langton SR. Urea hydrolysis in patients with Campylobacter pyloridis infection. Lancet 1986;i:965-6.

30 Thomsen L, Tasman-Jones C, Morris A, Wiggins P, Lees S Forlong $\mathrm{C}$. Ammonia produced by Campylobacter pylori neutralises $\mathrm{H}^{+}$moving through gastric mucus. Scand $J$ Gastroenterol 1989;24:761-8.

31 Pearson JP, Allen A, Parry S. A 70,000 molecular weight protein isolated from purified pig gastric mucus glycoprotein by reduction of disulphide bridges and its implications in the polymeric structures. Biochem J 1981; 197:155-62.

32 Gwazdzinski K, Liau YH, Slomiany A, Slomiany BL. Effect of associated and covalently bound lipids on the binding of hydrophobic fluorescent probes to gastric mucin. Gastroenterology 1986;90:1446.

33 Rose MC, Voter WA, Brown CF, Kaufman B. Structural features of human tracheobronchial mucus glycoprotein. Biochem J 1984:222:371-7.

34 Slayter HS, Lamblin G, Le Treut A, Galabert C, Houdret N. Complex structure of human bronchial mucus glycoprotein. Eur J Biochem 1984;142:209-18.

35 Slomiany BL, Nishikawa H, Slomiany A. Gastric mucin hydrophobicity: effects of proteolysis, reduction and lipid removal. Gastroenterology 1989;96(Suppl):A478.

36 Hazell SL, Lee A, Brody L, Hennessy W. Campylobacter pyloridis and gastritis: association with intercellular spaces and adaptation to an environment of mucus as important factors in colonisation of the gastric epithelium. $J$ Infect Dis 1986;153:658-63.

37 Eaton KA, Morgan DR, Brooks C, Krakowka S. Essential role of urease in the pathogenesis of gastritis induced by Helicobacter pylori in gnotobiotic piglets. Gastroenterology 1990;98:A654. 